\title{
How Supply Chain Integration Affects Innovation in a Digital Age: Moderating Effects of Sustainable Policy
}

\author{
Qiang Xu ${ }^{1}$, Qianqian Hu ${ }^{1}$, Tachia Chin ${ }^{1, *}{ }^{\mathbb{D}}$, Chen Chen ${ }^{1}$, Yi Shi ${ }^{1}$ and Jianxin $\mathrm{Xu}^{2}$ \\ 1 School of Management, Zhejiang University of Technology, Hangzhou 310023, China; \\ xuqiang@zjut.edu.cn (Q.X.); ruthhqq@163.com (Q.H.); chenchenzz0311@163.com (C.C.); \\ shiyi_41@163.com (Y.S.) \\ 2 School of Management, Hangzhou Dianzi University, Hangzhou 310023, China; leoxu007@gmail.com \\ * Correspondence: tachia1231@yahoo.com.sg
}

Received: 6 August 2019; Accepted: 27 September 2019; Published: 1 October 2019

\begin{abstract}
With the rapid development of digital technologies and increasing public attention on environmental problems, it has become a new challenge for global enterprises to manage supply chains responsibly, so as to improve their innovation performance for sustainability. Prior works have identified the effects of supply chain integration on firm innovation in advanced economies; however, so far, there has been limited research on the relationships between supply chain integration and firm innovation in emerging and developing countries. Hence, building upon transaction cost and resource dependence theories, this study used China's manufacturing industry as the research setting, probing the dynamic mechanisms between supply chain integration and firm innovation. The results show that the degree of supply chain integration positively relates to firms' patent output but negatively relates to their innovation efficiency, and that a sustainable policy moderates the foregoing associations. Our study enriches the body of knowledge regarding responsible supply chain integration in a new digital age with growing ecological concerns and thereby offers insightful practical implications for practitioners and policy makers.
\end{abstract}

Keywords: supply chain integration; policy; innovation efficiency; sustainable development; patent

\section{Introduction}

The continuous degradation of the ecological environment has gained an increasing amount of attention from global enterprises in recent years. Thus, promoting the sustainable development of the supply chain by strengthening energy-saving measures and corporate social responsibility (CSR) has become an important topic [1,2]. The conventional concept of supply chain integration (SCI) refers to the degree to which a manufacturer, with the aim of reducing costs as well as enhancing efficiency and economic value, strategically collaborates with its various partners (e.g., suppliers, customers, and other stakeholders) by integrating their materials, information, and capital flows and synchronizing their inter- and intraorganizational processes into a more comprehensive system [3]. Traditionally, SCI did not place much emphasis on CSR concerns. However, as mentioned at the outset, the implementation of environmental and social policies in SCI has become a prominent trend nowadays [2], and the governments of many countries have enacted policies to support the establishment of sustainable supply chains [4]. It is thus vital to further investigate the effect of sustainable policies on SCI-related issues in this new era.

In the past, $\mathrm{SCI}$, which comprises planning, sourcing, production, and distribution, often required some time to configure and integrate different types of resources [5]. However, with the rise of Industry 
Version 4.0, various types of advanced technologies, for example, cloud computing, big data, and block chain, have largely simplified the complex structure and accelerated the speed of SCI [3-5]. In this vein, focal companies of the supply chain today are expected to more easily draw on the integration of a wide range of knowledge and information at the global level to conduct innovation. Nevertheless, hitherto existing evidence regarding SCI-innovation associations mostly comes from the manufacturing industry of developed countries, and research focusing on developing or emerging economies is still limited [6,7]. Given that quite a few emerging and developing nations with the advantage of a large amount of surplus labor (e.g., India, China, and Vietnam) have gained increasing importance in global supply chains [7], it is imperative to obtain a better understanding of the impact of SCI upon firm innovation in such a context.

Considering the foregoing arguments, the main purpose of this paper is to fill the above-mentioned gap by exploring the mechanisms among SCI, firm innovation, and sustainable policies within a non-developed, highly digitalized context with growing ecological concerns. As China is the world's biggest emerging economy and there is an ongoing transformation of this nation's manufacturing industry, we used China's manufacturing sector as the background to conduct our research. It is worth noting that the Chinese government always plays a dominant role in the allocation and distribution of crucial resources to firms by launching policies $[1,6,7]$. We thus also tested the moderating effect of the most relevant sustainable policy (i.e., strategic emerging industry policy in our case) on SCI-innovation relations.

Overall, this study makes three main contributions: First, incorporating the perspectives of transaction cost and resource dependency, we provide valuable evidence from a non-Western context (i.e., China), thus enriching the body of knowledge regarding how responsible management of SCI (i.e., responsible SCI), which refers to broadening the boundaries of companies' social responsibilities to their SCI [2], impacts firm innovation in such a new digital era riddled with CSR concerns. Second, to a certain extent, we distinguish "innovation quality" from "innovation quantity" by using both "innovation efficiency" and "patent output" as our measures, which deepens our understanding of relevant issues. Third, we examine the moderating effect of China's recent sustainable policy on SCI-innovation mechanisms, thereby offering insightful practical implications for practitioners and policy makers.

\section{Literature Review and Hypotheses Development}

\subsection{SCI and Innovation With Ecological Concerns: Resource Dependency and Transaction Cost Theories}

In terms of SCI practice, traditionally, there was usually one large-size enterprise (mostly a famous brand or a multinational corporation) as a focal organization to preside over the entire supply chain process, which covered raw material procurement, manufacturing and assembly of finished products, transportation of products, and delivery to the end user [4,5]. Such SCI in general pays particular attention to the process-oriented internal synthesis of production, logistics, and marketing activities within or dominated by the leading/core firm [8]. However, along with the coming of the new digital age, advanced technologies have enabled firms to synchronously share and process a massive amount of information and knowledge across organizational and national borders. More specifically, all functional units within the supply chain can be integrated into a more complex virtual system in which research and development (R\&D), manufacturing, logistics, and marketing activities are completed through the coordination of a variety of independent modules that include one or more organizations [8,9]. This new, modern type of SCI often involves both internal (e.g., intraorganizational integration) and external (e.g., customer and supplier integration) dimensions [5], whereby firms can concentrate on their specialized areas and complete other functions through strategic alliance and cooperation with diverse partners along the supply chain. Such SCI goes beyond organizational boundaries, thus enabling firms to effectively avoid making costly (and probably risky) investments, 
particularly those highly asset-specific and customized ones because not all critical activities and services need to be carried out independently in-house [8-10].

To a certain extent, the foregoing arguments echo the perspective of the transaction cost theory (TCT) [11], which has been used to explain how the focal/leading company of the supply chain, based on the associated transaction costs, decides whether a specific activity (e.g., design, manufacture, and logistics) as an economic exchange should be managed internally within the organization or contracted out to its external strategic partner (i.e., outsourcing) [12]. The literature also indicates that the resource dependence theory (RDT) [11] can be employed to address why some focal firms of the supply chain decided not to increase dependence on external strategic partners for expense saving but to invest in keeping key resources in their own hands to create distinctive competitive advantages [13-15]. Due to the popularity of digitalized SCI coupled with rising ecological considerations, when engaging in innovation, leading firms of the supply chain have to confront new challenges about how to achieve a better trade-off between reducing transaction costs and gaining more critical resources over rivals. Taking into account the foregoing contentions, TCT and RDT can be deemed as two important perspectives for investigating the relationship between SCI and firm innovation. We therefore applied TCT and RDT to develop our theoretical logic presented below.

\subsection{Hypotheses Development}

It is widely recognized that $R \& D$ efficiency and number of patents are key indicators to measure innovation performance in the supply chain [15-19]. However, in terms of the relationships between SCI and firm innovation, the current research shows inconsistent results. For instance, Lahiri et al. (2013) claimed that the level of SCI is negatively related to focal firms' patent numbers but positively related to their net incomes [18]. Li et al. (2010) discovered that the SCI level of information technology (IT) enterprises has an inverted U-shaped relationship with the quality level of patents [19]. Such discrepancies may be attributed to the crucial challenges caused by the deepening of the green supply chain concept coupled with the popularization of the Internet and technology. On the one hand, this leads focal firms to more easily manage their strategic partners and to increase the sustainability of their supply chains; on the other hand, this also implies a huge amount of investment into the implementation of more stringent environmental standards that may increase operation risks.

China's manufacturing sector, where industrial upgrading has led firms to build new digital platforms for $\mathrm{SCI}$, is suffering from increasingly critical environmental pollution issues. Manufacturing firms in this context are confronted with serious pressure to coordinate CSR and commercial performance. According to the TCT, the growing prominence of ecological concerns in SCI coupled with the emerging trend of digitalization indicates that more asset-specific investments and rising transaction costs related to CSR and IT are required in the economic exchanges among supply chain partners. Firms must introduce new digital technology with environmental and social considerations by recruiting knowledgeable IT specialists and purchasing environmentally friendly equipment. Hence, it is plausible that the R\&D time and expenses during the integration of the supply chain will increase, and SCI may thereby exert a negative impact on firm innovation efficiency. We thus posit.

Hypothesis 1a. In Chinese manufacturing, SCI negatively relates to firm innovation efficiency. Nevertheless, from the perspective of RDT, with the use of advanced digital technologies, leading enterprises today can effectively combine the diversified resources of its stakeholders at the early phase of product $R \mathcal{E} D$, at which point it may be easier to overcome the institutional constraints of immature markets and to create worldwide competitive advantages in a more green, sustainable way [20,21]. Adhering this logic, some aspiring entrepreneurs in Chinese manufacturing have indeed sought a long-term superior position by making best use of their vital resources to create distinctive competitive advantages that are difficult to imitate and replicate, such as producing and acquiring patents with ecological awareness (e.g., products that reduce energy consumption or can be recycled) [22,23]. More specifically, the logic of the RDT allows us to further argue that the quality of innovation as a more valuable, rare, and not easily substituted resource is more important than the quantity of innovation in 
SCI nowadays. It is plausible that the prevalence of achieving sustainable SCI may encourage firms to create more product patents. We thus hypothesize the following:

Hypothesis $\mathbf{1 b}$. In Chinese manufacturing, SCI positively relates to firm patent outcome.

Our research framework is shown as Figure 1.

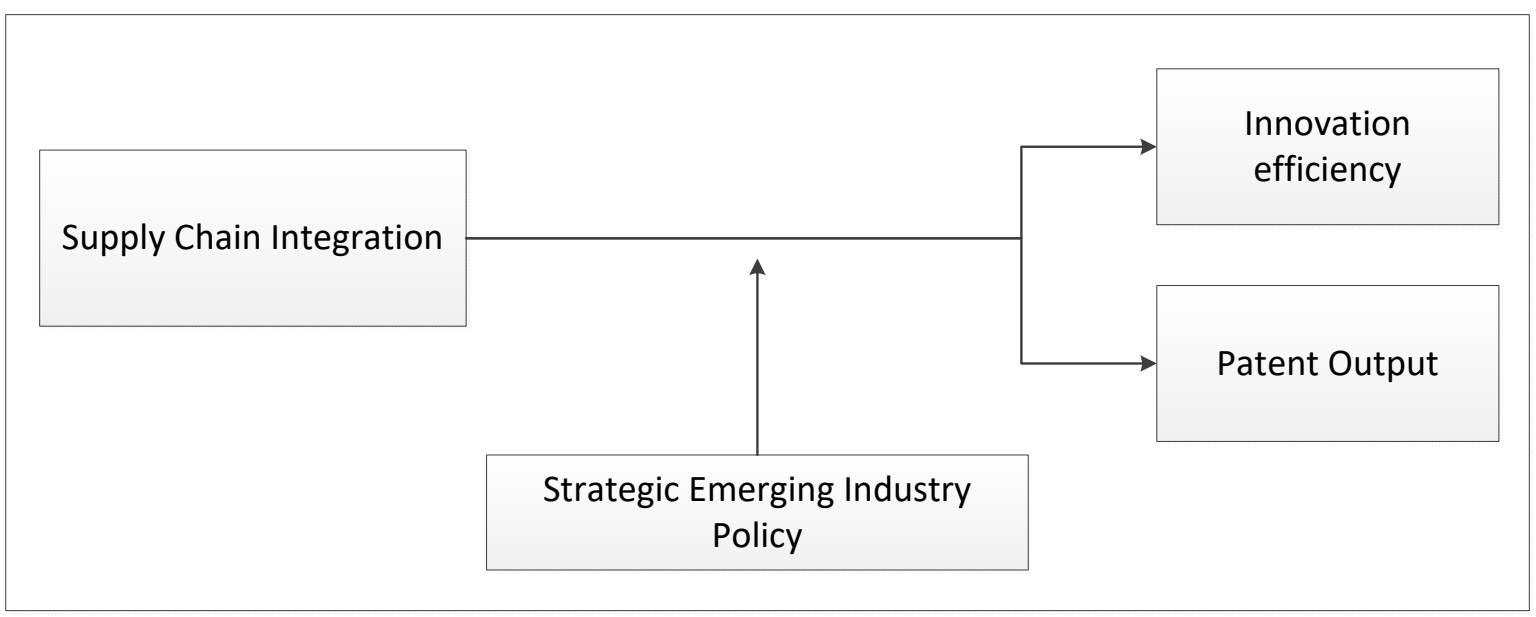

Figure 1. Conceptual Framework.

\subsection{The Moderating Effect of Sustainable Policy on SCI-Innovation Relations}

In terms of the Chinese manufacturing sector, the central government promulgated the strategic emerging industry policy in 2010, in which the establishment and responsible management of sustainable supply chains has been seen as one of the strategic priorities [24]. This sustainable policy, which requires firms to fully comply with more stringent environmental standards, provides strong support to nine industries characterized by low material and resource consumption, as well as high growth potential and comprehensive benefits (i.e., new-generation IT industry, high-end equipment manufacturing industry, new materials industry, biological industry, new-energy automotive industry, new-energy industry, energy-saving and environmental protection industry, digital creative industry, and relevant services industry). Echoing this policy, China's manufacturing sector has paid a considerable amount of attention to the implementation of green supply chain management $[25,26]$.

It is widely recognized that in China's unique institutional environment, the government always intervenes in the market by means of industrial policy that controls the distribution and allocation of critical natural resources [22,23]. According to the RDT, it is thus imperative for Chinese organizations to abide by the newly launched policies as soon as possible, so as to gain access to scarce and valuable strategic resources from the government for innovation and competition [23-26]. However, evidence also shows that in order to take greater advantage of the policy, some firms may frequently choose to engage in rent-seeking behaviors rather than dedicating themselves to the public welfare [26,27]. Scholars indicate that in China, excessive governmental interference into the market mechanism sometimes elicits quite a few side effects that often impede organizational innovation and even lead to political corruption $[5,23]$. In light of these debates, we contend that industrial policies may kindle or hinder corporate innovation in the Chinese context, which is a topic that requires further, deeper investigation.

As far as the relationship between SCI and firm innovation is concerned, some scholars have employed the TCT to discuss relevant issues in the Chinese context. For instance, Yang et al. (2015), based on a sample from the Bohai Rim region of China [28,29], and Julan et al. (2012), using the World Bank database of the Chinese manufacturing industry [25], both discovered that in an emerging market such as China, where the protection of intellectual property rights and asset specificity are weak and 
contract enforcement is imperfect, $\mathrm{SCI}$ is conducive to reducing transaction costs and the potential for opportunism. This is because SCI helps firms to act more agilely and to adapt more quickly to the ongoing technological changes and economic uncertainties; thus, they can better secure innovation outcomes [26].

China's strategic emerging industry policy allocates and directs abundant public resources to specifically selected industries and organizations according to the government's preference. Firms that are supported by such policies in general enjoy various tax exemption treatments and fiscal subsidies and have unique competitive advantages for innovation. Considering the foregoing discussion, we thus argue that the strategic emerging industry policy, as an important sustainable policy, may moderate SCI-innovation relationships:

Hypothesis 2a. The sustainable policy moderates the negative relationship between SCI and firm innovation efficiency, such that the negative SCI-innovation relationship is stronger in the presence of the sustainable policy;

Hypothesis $\mathbf{2 b}$. The sustainable policy moderates the positive relationship between SCI and firm patent outcome, such that the positive SCI-patent relationship is stronger in the presence of the sustainable policy.

\section{Research Design and Methodology}

\subsection{Sample Selection}

We used a sample of the listed companies in China's manufacturing sector at the Shanghai and Shenzhen stock exchanges from 2011 to 2017. Raw data were selected from the Win.d database (please refer to https://www.wind.com.cn/en/Default.html) and supplemented by the China Stock Market \& Accounting Research Database (CSMAR). Win.d is a renowned financial data and analytics tool provider which helped us obtain comprehensive corporate financial information, as its database includes more than $90 \%$ of Chinese listed enterprises. To control for extraneous variance, we referred to previous research [30], excluding financial companies (e.g., insurance companies and banks), nonprofit organizations, and special treatment (ST) companies. Also, companies with missing variable data were eliminated. We finally obtained 1722 usable data points for formal analysis and trimmed all the firm-level variables at the 1st and 99th percentiles to avoid outliers that would have distorted our results.

\subsection{Measures}

\subsubsection{Dependent Variables}

Referring to previous research [31], we used innovation efficiency (labeled PTE) and the proportion of the number of a firm's authorized patents to the average number of granted patents per firm in the manufacturing sector (labeled GPA11) to measure firm innovation performance.

The method of data envelopment analysis (DEA) was first proposed by Charnes et al. (1978) [32]. It is a non-parametric mathematical programming method using linear programming and convex analysis as tools to calculate the relative efficiency between the evaluated units [33]. Considering that there exist multiple inputs and outputs in a real production situation, the DEA method, which is capable of offering a comprehensive optimal input-output scheme out of the decision-making unit, is especially appropriate for measuring innovation efficiency [34,35].

In light of Bai's (2011) study [36], we created an aggregate patent measure (labeled GPA) with three indicators to evaluate firms' total innovation output. Three indicators (i.e., invention, utility model, and design patents) were given weights of $0.5,0.3$, and 0.2 , respectively. 


\subsubsection{Independent Variable}

Referring to previous research [19], SCI level (labeled VI) was measured as shown below:

$$
V I=V A S=\frac{\text { Added value }}{\text { Total output }}
$$

\subsubsection{Moderator}

Based on the main business activities and product portfolios disclosed in the annual reports, a firm supported by the strategic emerging industry policy was coded as 1 ; otherwise, it was coded as 0 (labeled IP).

\subsubsection{Control Variables}

Referring to prior studies [6,37], we controlled for the following variables: earnings before interest and tax (labeled EBIT), operating cash flow (labeled CF), property nature (labeled property), company age (labeled age), firm size (labeled size), long-term debt ratio (labeled Lev), sales expense (labeled Adv), R\&D expense (labeled RDs), and return on equity (labeled ROE). Referring to the literature [38-40], we also controlled for complementary assets (labeled CAS), which are believed to influence firm innovation performance.

\subsection{Model Specification}

According to the theoretical hypotheses, we constructed the following two regression models (please refer to Table 1 for more details).

Table 1. Definitions of variables.

\begin{tabular}{|c|c|c|}
\hline \multicolumn{2}{|c|}{ Variable } & Definition and Measurement \\
\hline \multirow{5}{*}{ Dependent Variables } & PTE & $\begin{array}{l}\text { Innovation efficiency is calculated by the DEA method as } \\
\text { illustrated above. }\end{array}$ \\
\hline & GPA11 & $\begin{array}{c}\text { The proportion of the number of a firm's authorized patent } \\
\text { to the average number of the granted patents per firm in } \\
\text { the manufacturing sector as described above. }\end{array}$ \\
\hline & GPA_invent & The number of invention patent authorizations. \\
\hline & GPA_design & The number of design patent authorizations. \\
\hline & GPA_utility & The number of utility model patent authorizations. \\
\hline Independent Variable & VI & The degree of SCI, VI = VAS = added value/total output. \\
\hline Moderator & IP & $\begin{array}{c}\text { Firm supported by the policy is } 1 \text { and } 0 \text { otherwise (dummy } \\
\text { variable). }\end{array}$ \\
\hline \multirow{11}{*}{ Control Variables } & EBIT & $\begin{array}{c}\text { Earnings before interest and tax, EBIT = Earnings before } \\
\text { interest and tax/operating income. }\end{array}$ \\
\hline & $\mathrm{CF}$ & $\begin{array}{l}\text { Operating cash flow, } \mathrm{CF}=\text { operating cash flow/total assets. } \\
\text { complementary assets, } \mathrm{CAS}=\text { (machine and equipment }\end{array}$ \\
\hline & CAS & value + sales expense + cash paid to and for \\
\hline & & staffs)/commodity and labor cash incomes \\
\hline & Property & $\begin{array}{c}\text { Property nature, which is } 1 \text { for state-owned enterprises } \\
\text { and } 0 \text { otherwise. }\end{array}$ \\
\hline & Age & $\begin{array}{c}\text { Company age, Age = (observation year }- \text { incorporation } \\
\text { year })+1 .\end{array}$ \\
\hline & Size & Enterprise size, size $=\ln$ total assets. \\
\hline & Lev & Long-term debt ratio, Lev = long-term debts/assets. \\
\hline & Adv & Sales expense, $\mathrm{Adv}=$ sales expense/operating income. \\
\hline & $\mathrm{ROE}$ & Return on equity, ROE = net returns/net assets. \\
\hline & RDs & R\&D expense, RDs = R\&D expense/operating income. \\
\hline
\end{tabular}


Model 1 was built for testing Hypotheses 1a and 1b. The standard error of robustness was adopted to avoid heteroskedasticity [41,42]:

$$
\begin{aligned}
\mathrm{PTE}_{i, t} / G P A_{i, t} & =\alpha_{0}+\alpha_{1} \operatorname{VI}_{i, t}+\alpha_{2} \mathrm{EBIT}_{i, t}+\alpha_{3} C F_{i, t}+\alpha_{4} C A S_{i, t}+\alpha_{5} \text { Property }_{i, t} \\
& +\alpha_{6} \text { Age }_{i, t}+\alpha_{7} \text { Size }_{i, t}+\alpha_{8} \operatorname{Lev}_{i, t}+\alpha_{9} A d v_{i, t}+\alpha_{10} \text { ROE }_{i, t}+\alpha_{11} R D s_{i, t}
\end{aligned}
$$

Model 2 was built for testing Hypotheses $2 \mathrm{a}$ and $2 \mathrm{~b}$. VI ${ }^{*} \mathrm{IP}$, as the interaction term, represents the moderating effect. If the result of $\alpha_{1}$ is significant, the moderating effect is valid:

$$
\begin{aligned}
\frac{P T E_{i, t}}{\overline{G P A}_{i, t}} & =\alpha_{0}+\alpha_{1} V I_{i, t} \times I P_{i, t-1}+\alpha_{2} V I_{i, t}+\alpha_{3} I P_{i, t-1}+\alpha_{4} E B I T_{i, t}+\alpha_{5} C F_{i, t} \\
& +\alpha_{6} C_{1} A S_{i, t}+\alpha_{7} \text { Property }_{i, t}+\alpha_{8} A g e_{i, t}+\alpha_{9} \operatorname{Size}_{i, t}+\alpha_{10} \text { Lev }_{i, t} \\
& +\alpha_{11} A d v_{i, t}+\alpha_{12} \text { ROE }_{i, t}+\alpha_{13} \text { RDs }_{i, t}
\end{aligned}
$$

In Models 2 and 3, $P T E_{i, t}$ is the innovation efficiency of firm $i$ at period $t ; G P A 11_{i, t}$ is the proportion of the number of a firm's authorized patents to the average number of the granted patents per firm in the manufacturing sector; $V I_{i, t}$ is the degree of $\mathrm{SCI}$ of firm $\mathrm{i}$ at period $\mathrm{t}$; and $E B I T_{i, t}, C F_{i, t}, C A S_{i, t}$, Property $_{i, t}, A g e_{i, t}$, Size $_{i, t}, L e v_{i, t}, A d v_{i, t}, R O E_{i, t}$, and $R D s_{i, t}$ represent earnings before interest and tax, operating cash flow, complementary assets, property nature, enterprise age, enterprise size, long-term debt ratio, sales expense, return on equity, and $R \& D$ expense of firm $i$ at period $t$, respectively (please refer to Table 1). In addition, in Model $3 I P_{i, t-1}$ is the policy support of firm $\mathrm{i}$ at period $\mathrm{t}-1$.

Scholars argue that a hysteresis effect should be taken into consideration in the relationship between policy implementation and firm performance [43]. Therefore, we lagged all variables for one year to examine the impact of the sustainable policy on corporate innovation output.

PTE (innovation efficiency); the proportion of the number of a firm's authorized patents to the average number of the granted patents per firm in the manufacturing sector as described above (GPA11); VI (supply chain integration); IP (strategic emerging industry policy virtual variable); EBIT (earnings before interest and tax); CF (operating cash flow); CAS (complementary assets); property (property nature); Age (company age); Size (enterprise scale); Lev (long-term debt ratio); Adv (sales expense); ROE (return on equity); RDs (R\&D expense).

\section{Empirical Analysis}

\subsection{Descriptive Statistics}

Table 2 reports information and descriptive results of the main variables. As Table 2 shows, the mean value of PTE was 0.081 , its standard deviation was 0.108 , the minimum value was 0.003 , and the maximum value was 0.742 . These results indicate that the innovation efficiency of our sample firms is generally low. However, the mean of GPA11 was 1.345 and the standard deviation was 2.569, indicating there may be large differences among the samples in terms of patent output. As for the control variables, the standard deviations of enterprise age and scale were 4.437 and 1.154, respectively. This shows that the age and size of the enterprise are quite different among the sample companies, and that the age difference of the enterprise is greater than the difference of the scale of the enterprise. 
Table 2. Statistic description of related variables.

\begin{tabular}{cccccc}
\hline Variable & Observation Value & Mean Value & Standard Deviation & Minimum Value & Maximum Value \\
\hline PTE & 1418 & 0.0806062 & 0.1076341 & 0.00338 & 0.742187 \\
GPA11 & 1425 & 1.345114 & 2.569318 & 0 & 19.4731 \\
VI & 1405 & 0.1491569 & 0.0694938 & 0.019481 & 0.4085363 \\
IP & 1441 & 0.5100625 & 0.5000723 & 0 & 1 \\
Moderator & 1405 & 0.0764787 & 0.0876301 & 0 & 0.4085363 \\
EBIT & 1409 & 0.0698222 & 0.0851894 & -0.143194 & 0.5788783 \\
CF & 1416 & 0.042758 & 0.0607939 & -0.138388 & 0.2417022 \\
CAS & 1410 & 0.6096447 & 0.3899659 & 0.0586145 & 2.351202 \\
Property & 1441 & 0.6766135 & 0.4679312 & 0 & 1 \\
Age & 1441 & 18.93963 & 4.436571 & 5 & 38 \\
Size & 1414 & 22.53074 & 1.154382 & 20.05804 & 25.94896 \\
Lev & 1427 & 0.0827147 & 0.0763854 & 0 & 0.3315441 \\
Adv & 1411 & 0.0685278 & 0.0767476 & 0.00282 & 0.4277569 \\
ROE & 1410 & 0.0712884 & 0.0852229 & -0.297101 & 0.3617772 \\
RDs & 1401 & 0.0278511 & 0.01875 & 0.0005302 & 0.1010012 \\
\hline
\end{tabular}

\subsection{Regression Result Analysis}

Table 3 shows the models addressing the SCI-innovation relationships and the moderating effects of the sustainable policy on such relationships.

Table 3. Regression results.

\begin{tabular}{|c|c|c|c|c|}
\hline Variable & $\begin{array}{l}\text { Innovation Efficiency } \\
\text { (Model 1a) }\end{array}$ & $\begin{array}{l}\text { Patent Output } \\
\text { (Model 1b) }\end{array}$ & $\begin{array}{c}\text { Innovation Efficiency } \\
\text { (Model 2a) With Moderator }\end{array}$ & $\begin{array}{c}\text { Patent Output (Model 2b) } \\
\text { With Moderator }\end{array}$ \\
\hline Moderator & & & $\begin{array}{l}-0.269 * * * \\
-0.0714\end{array}$ & $\begin{array}{l}-3.208^{*} \\
-1.6400\end{array}$ \\
\hline IP & & & $\begin{array}{l}0.0492^{* * *} \\
-0.0138\end{array}$ & $\begin{array}{c}0.545^{*} \\
-0.2960\end{array}$ \\
\hline VI & $\begin{array}{c}-0.223^{* * *} \\
-0.0631\end{array}$ & $\begin{array}{l}3.779 * * \\
-1.5490\end{array}$ & $\begin{array}{l}-0.110 * \\
-0.0651\end{array}$ & $\begin{array}{l}5.143 * * * \\
-1.4100\end{array}$ \\
\hline EBIT & $\begin{array}{c}-0.114^{* * *} \\
-0.0366\end{array}$ & $\begin{array}{c}-5.190 * * * \\
-0.8690\end{array}$ & $\begin{array}{c}-0.117^{* * *} \\
-0.0369\end{array}$ & $\begin{array}{c}-5.213 * * * \\
-0.8650\end{array}$ \\
\hline $\mathrm{CF}$ & $\begin{array}{l}-0.108^{* *} \\
-0.0515\end{array}$ & $\begin{array}{l}-4.168^{* * *} \\
-1.0450\end{array}$ & $\begin{array}{l}-0.100 * \\
-0.0512\end{array}$ & $\begin{array}{l}-4.103 * * * \\
-1.0560\end{array}$ \\
\hline CAS & $\begin{array}{l}-0.0406^{* * *} \\
-0.0072\end{array}$ & $\begin{array}{l}-0.985^{* * *} \\
-0.1390\end{array}$ & $\begin{array}{l}-0.0385^{* * * *} \\
-0.0072\end{array}$ & $\begin{array}{l}-0.971 * * * \\
-0.1400\end{array}$ \\
\hline Property & $\begin{array}{l}-0.0117^{*} \\
-0.0067\end{array}$ & $\begin{array}{l}-0.1420 \\
-0.1150\end{array}$ & $\begin{array}{l}-0.0110 * \\
-0.0066\end{array}$ & $\begin{array}{l}-0.1360 \\
-0.1150\end{array}$ \\
\hline Age & $\begin{array}{l}-0.0007 \\
-0.0007\end{array}$ & $\begin{array}{l}-0.0102 \\
-0.0144\end{array}$ & $\begin{array}{l}-0.0006 \\
-0.0007\end{array}$ & $\begin{array}{l}-0.0091 \\
-0.0144\end{array}$ \\
\hline Size & $\begin{array}{l}0.0110^{* * * *} \\
-0.0035\end{array}$ & $\begin{array}{l}1.163^{* * *} \\
-0.0906\end{array}$ & $\begin{array}{l}0.00975^{* * *} \\
-0.0036\end{array}$ & $\begin{array}{l}1.151 * * * \\
-0.0941\end{array}$ \\
\hline Lev & $\begin{array}{l}-0.0078 \\
-0.0458\end{array}$ & $\begin{array}{c}0.7450 \\
-1.0070\end{array}$ & $\begin{array}{l}-0.0089 \\
-0.0451\end{array}$ & $\begin{array}{c}0.7380 \\
-1.0030\end{array}$ \\
\hline Adv & $\begin{array}{c}0.0202 \\
-0.0284\end{array}$ & $\begin{array}{l}-0.7930 \\
-0.5090\end{array}$ & $\begin{array}{c}0.0238 \\
-0.0284\end{array}$ & $\begin{array}{l}-0.7670 \\
-0.5110\end{array}$ \\
\hline $\mathrm{ROE}$ & $\begin{array}{l}0.198^{* * *} \\
-0.0489\end{array}$ & $\begin{array}{l}3.998^{* * *} \\
-1.4240\end{array}$ & $\begin{array}{l}0.217^{* * *} \\
-0.0505\end{array}$ & $\begin{array}{l}4.186^{* * *} \\
-1.4720\end{array}$ \\
\hline RDs & $\begin{array}{c}0.1410 \\
-0.1570\end{array}$ & $\begin{array}{l}25.84^{* * * *} \\
-3.7440\end{array}$ & $\begin{array}{c}0.0958 \\
-0.1620\end{array}$ & $\begin{array}{l}25.49 * * * \\
-4.0530\end{array}$ \\
\hline Constant & $\begin{array}{l}-0.0964 \\
-0.0766\end{array}$ & $\begin{array}{c}-24.99^{* * *} \\
-2.0660\end{array}$ & $\begin{array}{l}-0.0948 \\
-0.0785\end{array}$ & $\begin{array}{c}-25.01 * * * \\
-2.0960\end{array}$ \\
\hline $\begin{array}{c}\text { Observations } \\
\mathrm{R}^{2}\end{array}$ & $\begin{array}{c}1220.0000 \\
0.0780\end{array}$ & $\begin{array}{c}1229.0000 \\
0.3500\end{array}$ & $\begin{array}{c}1220.0000 \\
0.0870\end{array}$ & $\begin{array}{c}1229.0000 \\
0.3520\end{array}$ \\
\hline
\end{tabular}

Note: (1) The upper figure is the estimation coefficient and the lower figure is the cluster robustness standard error in the table; $(2)^{* * * * * *}$ and * indicate a significance level of $1 \%, 5 \%$ and $10 \%$, respectively.

Models $1 \mathrm{a}$ and $1 \mathrm{~b}$ explain the associations between SCI and firm innovation performance. In Model 1a, we ran an Ordinary Least Square (OLS) model to test the effect of SCI on PTE and discovered that 
the coefficient of VI was significantly negative $(\alpha=-0.223, p<0.001)$. Hypothesis $1 \mathrm{a}$ is thus supported. In Model 1b, we tested the effect of SCI on GPA11, and the coefficient of VI was found to be significantly positive $(\alpha=3.779, p<0.05)$. The results provide support for Hypothesis $1 \mathrm{~b}$.

Models $2 \mathrm{a}$ and $2 \mathrm{~b}$ explain the moderating effect of the sustainable policy on the SCI-innovation associations. In order to introduce the moderator, all main variables were mean-centered. Taking a closer look at our models, we found that the model fit of Model $2 \mathrm{a}$ and $2 \mathrm{~b}\left(R^{2}=0.08\right.$ and 0.352 , respectively) was better than that of Model 1a and $1 \mathrm{~b}\left(R^{2}=0.078\right.$ and 0.350 , respectively). As Model 2a shows, the regression coefficient of the moderator was significantly negative $(\alpha=-0.269, p<0.001)$, while Model $2 \mathrm{~b}$ reveals that the regression coefficient of the moderator was significantly negative $(\alpha=-3.208, p<0.1)$. We therefore validated the moderating effects of the strategic emerging industry policy on both SCI-PTE and SCI-GPA11associations. Hypotheses $2 \mathrm{a}$ and $2 \mathrm{~b}$ are supported as well.

In order to more clearly characterize the moderating mechanisms, simple slope tests were used to evaluate whether the relationship (slope) between $\mathrm{SCI}$ and innovation performance is significant at a particular value of our moderator. To perform the simple slope test, the slope itself was calculated by substituting the value of our moderator into the regression equation. Figure 2 shows that the support of the strategic emerging industry policy can weaken the negative correlation of SCI and innovation efficiency. Figure 3 shows that SCI and patent output have stronger positive correlations with the presence of the strategic emerging industry policy. Our hypotheses are further validated.

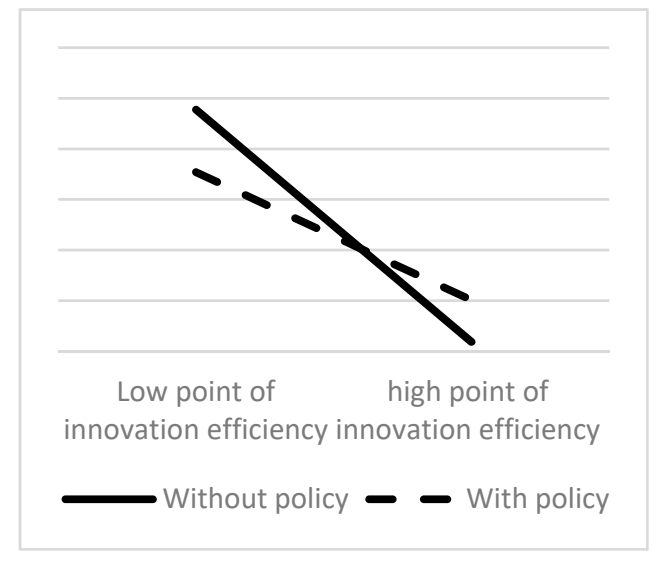

Figure 2. Regulatory effects of SCI-PTE.

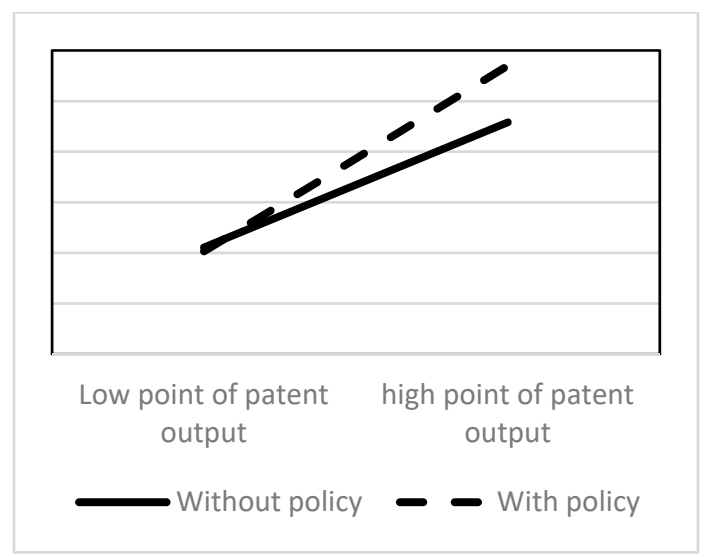

Figure 3. Regulatory effects of SCI-GPA11.

Regarding the control variables, earnings before interest and tax (EBIT) and complementary assets (CAS) had a significant negative correlation with innovation efficiency, and enterprise size (Size) and return on equity (ROE) had a significant positive correlation with innovation efficiency in Models $1 \mathrm{a}$ and 2a. In Models $1 \mathrm{~b}$ and 2b, earnings before interest and tax (EBIT) and complementary assets 
(CAS) had a significant negative correlation with innovation patent output, and enterprise size (Size), return on equity (ROE), and R\&D expense (RDs) had a significant positive correlation with innovation patent output.

\subsection{Robustness Check}

In order to enhance the methodological rigor, we double-checked the model fit and accuracy of our OLS regression results by employing another two statistical techniques to validate our assumptions. Considering our variable "patent output" (GPA11) is zero-inflated count data, we built a zero-inflated Poisson regression model to re-examine part of our findings on patent output [44], whereas the Tobit analysis may complement the deficiency of the OLS model in terms of measuring production and innovation efficiency [45]; we thus also employed the Tobit approach to further verify our findings on innovation efficiency (PTE). In Table 4, Models 1a and 2a show the results of the Tobit regression analysis while Models $1 \mathrm{~b}$ and $2 \mathrm{~b}$ show the results of the zero-inflated Poisson regression model. According to Models 1a, 2a and 1b, H1a $(p<0.01), \mathrm{H} 2 \mathrm{a}(p<0.01)$ and $\mathrm{H} 1 \mathrm{~b}(p<0.05)$ are fully supported; although $\mathrm{H} 2 \mathrm{~b}(p>0.1)$ is not supported, the correlation direction is still the same. Given the foregoing outcomes, we argue that it is appropriate to proceed to conduct the robustness check.

Table 4. Alternative Approaches.

\begin{tabular}{|c|c|c|c|c|}
\hline Variable & $\begin{array}{l}\text { Innovation Efficiency } \\
\text { (Model 1a) }\end{array}$ & $\begin{array}{l}\text { Patent Output } \\
\text { (Model 1b) }\end{array}$ & $\begin{array}{c}\text { Innovation Efficiency } \\
\text { (Model 2a) With Moderator }\end{array}$ & $\begin{array}{l}\text { Patent Output (Model } \\
\text { 2b) With Moderator }\end{array}$ \\
\hline Moderator & & & $\begin{array}{c}-0.269^{* * *} \\
-0.085\end{array}$ & $\begin{array}{l}-1.372 \\
-1.837\end{array}$ \\
\hline IP & & & $\begin{array}{l}0.0492^{* * *} \\
-0.0143\end{array}$ & $\begin{array}{c}1.333 \\
-529.1\end{array}$ \\
\hline VI & $\begin{array}{c}-0.223 * * * \\
-0.0718\end{array}$ & $\begin{array}{c}2.664 * * \\
-1.339\end{array}$ & $\begin{array}{c}-0.11 \\
-0.0799\end{array}$ & $\begin{array}{l}3.672 * \\
-1.899\end{array}$ \\
\hline EBIT & $\begin{array}{l}-0.114^{* *} \\
-0.0526\end{array}$ & $\begin{array}{l}-1.934^{*} \\
-1.172\end{array}$ & $\begin{array}{l}-0.117^{* *} \\
-0.0524\end{array}$ & $\begin{array}{l}-2.005^{*} \\
-1.176\end{array}$ \\
\hline $\mathrm{CF}$ & $\begin{array}{l}-0.108^{*} \\
-0.0572\end{array}$ & $\begin{array}{l}0.772 \\
-0.72\end{array}$ & $\begin{array}{l}-0.100^{*} \\
-0.0571\end{array}$ & $\begin{array}{c}0.81 \\
-0.721\end{array}$ \\
\hline CAS & $\begin{array}{l}-0.0406^{* * *} \\
-0.00838\end{array}$ & $\begin{array}{c}0.184 \\
-0.257\end{array}$ & $\begin{array}{l}-0.0385^{* * *} \\
-0.00839\end{array}$ & $\begin{array}{c}0.174 \\
-0.257\end{array}$ \\
\hline Property & $\begin{array}{l}-0.0117^{*} \\
-0.00639\end{array}$ & $\begin{array}{c}0.311 \\
-607.2\end{array}$ & $\begin{array}{l}-0.0110^{*} \\
-0.00636\end{array}$ & $\begin{array}{c}0.169 \\
-630.6\end{array}$ \\
\hline Age & $\begin{array}{l}-0.000695 \\
-0.000698\end{array}$ & $\begin{array}{l}-0.0903 * * * \\
-0.0287\end{array}$ & $\begin{array}{l}-0.000557 \\
-0.000696\end{array}$ & $\begin{array}{c}-0.0898 * * * \\
-0.0287\end{array}$ \\
\hline Size & $\begin{array}{l}0.0110^{* * *} \\
-0.00293\end{array}$ & $\begin{array}{c}0.840 * * * \\
-0.158\end{array}$ & $\begin{array}{l}0.00975^{* * *} \\
-0.00295\end{array}$ & $\begin{array}{c}0.846^{* * *} \\
-0.158\end{array}$ \\
\hline Lev & $\begin{array}{l}-0.00777 \\
-0.0451\end{array}$ & $\begin{array}{l}-0.462 \\
-0.64\end{array}$ & $\begin{array}{l}-0.00886 \\
-0.0449\end{array}$ & $\begin{array}{l}-0.54 \\
-0.648\end{array}$ \\
\hline Adv & $\begin{array}{c}0.0202 \\
-0.0394\end{array}$ & $\begin{array}{c}0.317 \\
-2.391\end{array}$ & $\begin{array}{c}0.0238 \\
-0.0392\end{array}$ & $\begin{array}{l}0.409 \\
-2.39\end{array}$ \\
\hline ROE & $\begin{array}{l}0.198^{* * *} \\
-0.0658\end{array}$ & $\begin{array}{l}-1.552 * \\
-0.87\end{array}$ & $\begin{array}{l}0.217^{* * *} \\
-0.0657\end{array}$ & $\begin{array}{c}-1.533 * \\
-0.87\end{array}$ \\
\hline RDs & $\begin{array}{c}0.141 \\
-0.159\end{array}$ & $\begin{array}{c}1.374 \\
-2.961\end{array}$ & $\begin{array}{l}0.0958 \\
-0.161\end{array}$ & $\begin{array}{c}1.405 \\
-2.959\end{array}$ \\
\hline Constant & $\begin{array}{l}-0.0964 \\
-0.0676\end{array}$ & $\begin{array}{l}-0.339 \\
-531.8\end{array}$ & $\begin{array}{l}-0.0903 \\
-0.0678\end{array}$ & $\begin{array}{l}-0.744 \\
-529.9\end{array}$ \\
\hline Observations & 1220 & 1222 & 1220 & 1222 \\
\hline
\end{tabular}

Note: (1) The upper figure is the estimation coefficient and the lower figure is the cluster robustness standard error in the table; (2) ${ }^{* * *},{ }^{* *}$ and * indicate a significance level of $1 \%, 5 \%$ and $10 \%$, respectively.

In order to check the sensitivity of our findings to the changes of the values of the key variables [46], three types of robustness checks were conducted to further validate our results. First, scholars have 
suggested adopting more diversified scales to evaluate firm innovation efficiency and performance, so as to draw more convincing conclusions [47-50]

As shown in Table 5, we thus used two different variables to measure innovation performance, namely, the proportion of the number of patent authorizations to the R\&D input (labeled Effc), and the number of total patent authorizations (labeled GPA) to replace original innovation efficiency and patent output variables. Second, as mentioned above, due to the presence of time hysteresis, a longer lag period should be taken into consideration when measuring SCI-innovation associations [51] and confirming the moderating effect of policy implementation on such relations [52]. Hence, as shown in Table 6, we used two-year lag data (from 2012 to 2017) to test the hypotheses. Third, for the sake of prudence, as shown in Table 7, we combined the two methods described above.

Table 5. Robustness Check 1.

\begin{tabular}{|c|c|c|c|c|}
\hline Variable & $\begin{array}{c}\text { Innovation } \\
\text { Efficiency (Effc) }\end{array}$ & $\begin{array}{l}\text { Patent Output } \\
\text { (GPA) }\end{array}$ & $\begin{array}{l}\text { Innovation Efficiency } \\
\text { (Effc) With Moderator }\end{array}$ & $\begin{array}{l}\text { Patent Output (GPA) } \\
\text { With Moderator }\end{array}$ \\
\hline Moderator & & & $\begin{array}{l}-7.72 \times 10^{-7 * * *} \\
-2.62 \times 10^{-7}\end{array}$ & $\begin{array}{l}-82.94^{* * *} \\
-28.7\end{array}$ \\
\hline IP & & & $\begin{array}{c}1.95 \times 10^{-7 * * *} \\
-4.78 \times 10^{-8}\end{array}$ & $\begin{array}{c}14.89 * * * \\
-5.249\end{array}$ \\
\hline VI & $\begin{array}{c}-6.00 \times 10^{-7 * *} \\
-2.48 \times 10^{-7}\end{array}$ & $\begin{array}{l}59.77 * * \\
-24.54\end{array}$ & $\begin{array}{l}-2.75 \times 10^{-7} \\
-2.41 \times 10^{-7}\end{array}$ & $\begin{array}{l}94.91^{* * *} \\
-24.45\end{array}$ \\
\hline EBIT & $\begin{array}{c}2.13 \times 10^{-7} \\
-1.63 \times 10^{-7}\end{array}$ & $\begin{array}{l}-83.33^{* * *} \\
-16.12\end{array}$ & $\begin{array}{c}1.85 \times 10^{-7} \\
-1.59 \times 10^{-7}\end{array}$ & $\begin{array}{l}-84.08 * * * \\
-16.15\end{array}$ \\
\hline $\mathrm{CF}$ & $\begin{array}{l}-3.29 \times 10^{-7 *} \\
-1.85 \times 10^{-7}\end{array}$ & $\begin{array}{l}-55.88^{* * *} \\
-18.74\end{array}$ & $\begin{array}{l}-2.64 \times 10^{-7} \\
-1.87 \times 10^{-7}\end{array}$ & $\begin{array}{l}-53.51^{* * *} \\
-18.78\end{array}$ \\
\hline CAS & $\begin{array}{c}2.49 \times 10^{-8} \\
-2.99 \times 10^{-8}\end{array}$ & $\begin{array}{l}-18.20^{* * *} \\
-2.558\end{array}$ & $\begin{array}{c}3.80 \times 10^{-7} \\
-3.04 \times 10^{-8}\end{array}$ & $\begin{array}{l}-17.71 * * * \\
-2.585\end{array}$ \\
\hline Property & $\begin{array}{l}-2.07 \times 10^{-8} \\
-2.36 \times 10^{-8}\end{array}$ & $\begin{array}{l}-3.555 \\
-2.198\end{array}$ & $\begin{array}{l}-1.62 \times 10^{-8} \\
-2.33 \times 10^{-8}\end{array}$ & $\begin{array}{l}-3.378 \\
-2.208\end{array}$ \\
\hline Age & $\begin{array}{l}-4.44 \times 10^{-9} \\
-2.73 \times 10^{-9}\end{array}$ & $\begin{array}{c}0.185 \\
-0.283\end{array}$ & $\begin{array}{l}-3.83 \times 10^{-9} \\
-2.70 \times 10^{-9}\end{array}$ & $\begin{array}{c}0.22 \\
-0.284\end{array}$ \\
\hline Size & $\begin{array}{l}-5.48 \times 10^{-8 * * *} \\
-1.17 \times 10^{-8}\end{array}$ & $\begin{array}{c}20.68^{* * *} \\
-1.484\end{array}$ & $\begin{array}{c}-6.19 \times 10^{-8 * * *} \\
-1.15 \times 10^{-8}\end{array}$ & $\begin{array}{c}20.31^{* * *} \\
-1.513\end{array}$ \\
\hline Lev & $\begin{array}{c}-3.31 \times 10^{-7} * * \\
-1.31 \times 10^{-7}\end{array}$ & $\begin{array}{c}24.04 \\
-18.12\end{array}$ & $\begin{array}{c}-3.14 \times 10^{-7} * * \\
-1.28 \times 10^{-7}\end{array}$ & $\begin{array}{c}24.21 \\
-17.93\end{array}$ \\
\hline Adv & $\begin{array}{c}5.51 \times 10^{-8} \\
-1.15 \times 10^{-7}\end{array}$ & $\begin{array}{l}-20.01 * * \\
-9.426\end{array}$ & $\begin{array}{c}7.90 \times 10^{-8} \\
-1.14 \times 10^{-7}\end{array}$ & $\begin{array}{l}-19.12 * * \\
-9.493\end{array}$ \\
\hline ROE & $\begin{array}{c}1.35 \times 10^{-7} \\
-2.58 \times 10^{-7}\end{array}$ & $\begin{array}{l}62.91^{* * *} \\
-22.98\end{array}$ & $\begin{array}{c}1.85 \times 10^{-7} \\
-2.56 \times 10^{-7}\end{array}$ & $\begin{array}{c}67.78 * * * \\
-23.66\end{array}$ \\
\hline RDs & $\begin{array}{c}-6.30 \times 10^{-6 * * *} \\
-7.40 \times 10^{-7}\end{array}$ & $\begin{array}{c}465.3^{* * *} \\
-62.11\end{array}$ & $\begin{array}{c}-6.67 \times 10^{-6 * * *} \\
-7.52 \times 10^{-7}\end{array}$ & $\begin{array}{l}451.7^{* * *} \\
-65.96\end{array}$ \\
\hline Constant & $\begin{array}{c}1.84 \times 10^{-6 * * *} \\
-2.71 \times 10^{-7}\end{array}$ & $\begin{array}{c}-449.5 * * * \\
-33.69\end{array}$ & $\begin{array}{c}1.89 \times 10^{-6 * * *} \\
-2.67 \times 10^{-7}\end{array}$ & $\begin{array}{c}-449.0 * * * \\
-34.04\end{array}$ \\
\hline Observations & 1240 & 1224 & 1240 & 1224 \\
\hline $\mathrm{R}^{2}$ & 0.125 & 0.357 & 0.14 & 0.362 \\
\hline
\end{tabular}

Note: (1) The upper figure is the estimation coefficient and the lower figure is the cluster robustness standard error in the table; $(2)^{* * *}, * *$ and * indicate a significance level of $1 \%, 5 \%$ and $10 \%$, respectively. 
Table 6. Robustness Check 2

\begin{tabular}{|c|c|c|c|c|}
\hline Variable & $\begin{array}{c}\text { Innovation } \\
\text { Efficiency (PTE) }\end{array}$ & $\begin{array}{l}\text { Patent Output } \\
\text { (GPA11) }\end{array}$ & $\begin{array}{l}\text { Innovation Efficiency } \\
\text { (PTE) with Moderator }\end{array}$ & $\begin{array}{c}\text { Patent Output (GPA11) } \\
\text { with Moderator }\end{array}$ \\
\hline Moderator & & & $\begin{array}{l}-0.283^{* * *} \\
-0.0712\end{array}$ & $\begin{array}{l}-3.382 * * \\
-1.47\end{array}$ \\
\hline IP & & & $\begin{array}{l}0.0457^{* * *} \\
-0.0134\end{array}$ & $\begin{array}{c}0.45 \\
-0.294\end{array}$ \\
\hline VI & $\begin{array}{l}-0.167^{* * *} \\
-0.0595\end{array}$ & $\begin{array}{l}3.796^{* * *} \\
-1.13\end{array}$ & $\begin{array}{l}-0.0537 \\
-0.0625\end{array}$ & $\begin{array}{l}5.138^{* * *} \\
-1.213\end{array}$ \\
\hline EBIT & $\begin{array}{l}-0.104^{* * *} \\
-0.0342\end{array}$ & $\begin{array}{l}-4.711^{* * *} \\
-0.852\end{array}$ & $\begin{array}{c}-0.105 * * * \\
-0.0345\end{array}$ & $\begin{array}{l}-4.698^{* * *} \\
-0.85\end{array}$ \\
\hline $\mathrm{CF}$ & $\begin{array}{l}-0.121^{* *} \\
-0.0539\end{array}$ & $\begin{array}{l}-4.094^{* * *} \\
-1.073\end{array}$ & $\begin{array}{l}-0.117 * * \\
-0.0542\end{array}$ & $\begin{array}{l}-4.116^{* * *} \\
-1.088\end{array}$ \\
\hline CAS & $\begin{array}{l}-0.0458^{* * *} \\
-0.00712\end{array}$ & $\begin{array}{l}-1.083^{* * *} \\
-0.127\end{array}$ & $\begin{array}{l}-0.0448^{* * *} \\
-0.0072\end{array}$ & $\begin{array}{l}-1.089 * * * \\
-0.131\end{array}$ \\
\hline Property & $\begin{array}{l}-0.0119 * \\
-0.00637\end{array}$ & $\begin{array}{l}-1.38 \times 10^{-1} \\
-1.14 \times 10^{-1}\end{array}$ & $\begin{array}{l}-0.0113 * \\
-0.00633\end{array}$ & $\begin{array}{l}-1.35 \times 10^{-1} \\
-1.14 \times 10^{-1}\end{array}$ \\
\hline Age & $\begin{array}{l}-0.000889 \\
-0.000789\end{array}$ & $\begin{array}{l}-0.0148 \\
-0.0155\end{array}$ & $\begin{array}{l}-0.000774 \\
-0.000793\end{array}$ & $\begin{array}{c}-0.014 \\
-0.0156\end{array}$ \\
\hline Size & $\begin{array}{l}0.0131^{* * *} \\
-0.00347\end{array}$ & $\begin{array}{l}1.182 * * * \\
-0.0917\end{array}$ & $\begin{array}{l}0.0122 * * * \\
-0.00357\end{array}$ & $\begin{array}{l}1.178^{* * *} \\
-0.0965\end{array}$ \\
\hline Lev & $\begin{array}{c}-0.00338 \\
-0.0438\end{array}$ & $\begin{array}{c}0.779 \\
-0.995\end{array}$ & $\begin{array}{c}-0.00488 \\
-0.043\end{array}$ & $\begin{array}{c}0.745 \\
-0.989\end{array}$ \\
\hline Adv & $\begin{array}{l}-0.0235 \\
-0.0245\end{array}$ & $\begin{array}{c}-1.209^{* * *} \\
-0.465\end{array}$ & $\begin{array}{l}-0.0216 \\
-0.0245\end{array}$ & $\begin{array}{c}-1.224^{* * *} \\
-0.469\end{array}$ \\
\hline ROE & $\begin{array}{l}0.156^{* * *} \\
-0.0478\end{array}$ & $\begin{array}{c}2.795 * * \\
-1.281\end{array}$ & $\begin{array}{c}0.173^{* * *} \\
-0.0489\end{array}$ & $\begin{array}{c}2.965^{* *} \\
-1.302\end{array}$ \\
\hline RDs & $\begin{array}{l}0.281 * \\
-0.152\end{array}$ & $\begin{array}{c}28.05^{* * *} \\
-3.801\end{array}$ & $\begin{array}{c}0.25 \\
-0.155\end{array}$ & $\begin{array}{c}28.15^{* * *} \\
-4.147\end{array}$ \\
\hline $\begin{array}{l}\text { Constant } \\
\text { Observations }\end{array}$ & $\begin{array}{c}-0.144^{*} \\
-0.0775 \\
1219\end{array}$ & $\begin{array}{c}-25.38^{* * *} \\
-2.1 \\
1232\end{array}$ & $\begin{array}{c}-0.147 * \\
-0.0796 \\
1219\end{array}$ & $\begin{array}{c}-25.50 * * * \\
-2.154 \\
1232\end{array}$ \\
\hline$R^{2}$ & 0.092 & 0.357 & 0.101 & 0.359 \\
\hline
\end{tabular}

Note: (1) The upper figure is the estimation coefficient and the lower figure is the cluster robustness standard error in the table; (2)***,** and * indicate a significance level of $1 \%, 5 \%$ and $10 \%$, respectively. (3) The time period of this regression is 2012-2017.

Table 7. Robustness Check 3.

\begin{tabular}{ccccc}
\hline Variable & $\begin{array}{c}\text { Innovation } \\
\text { Efficiency (Effc) }\end{array}$ & $\begin{array}{c}\text { Patent Output } \\
\text { (GPA) }\end{array}$ & $\begin{array}{c}\text { Innovation Efficiency (Effc) } \\
\text { Introduction of Moderator }\end{array}$ & $\begin{array}{c}\text { Patent Output (GPA) } \\
\text { Introduction of Moderator }\end{array}$ \\
\hline Moderator & & $-5.60 \times 10^{-7 * * *}$ & $-1.93 \times 10^{-7}$ & $-94.61^{* * *}$ \\
& & & $1.38 \times 10^{-7 * * *}$ & -29.27 \\
\hline IP & & & $-3.57 \times 10^{-8}$ & $15.99 * * *$ \\
& & & $-3.48 \times 10^{-7 *}$ & -5.472 \\
\hline VI & $-5.77 \times 10^{-7 * * *}$ & $70.11^{* * *}$ & $-1.83 \times 10^{-7}$ & $107.8^{* * *}$ \\
& $-2.00 \times 10^{-7}$ & -22.17 & $2.33 \times 10^{-8}$ & -24.15 \\
\hline EBIT & $3.86 \times 10^{-8}$ & $-79.96^{* * *}$ & $-9.49 \times 10^{-8}$ & $-80.32^{* * *}$ \\
& $-9.73 \times 10^{-8}$ & -16.41 & $-1.92 \times 10^{-7}$ & -16.54 \\
\hline CF & $-2.39 \times 10^{-7}$ & $-69.58^{* * *}$ & $-1.52 \times 10^{-7}$ & $-67.35^{* * *}$ \\
& $-1.49 \times 10^{-7}$ & -20.77 & & -20.83 \\
\hline
\end{tabular}


Table 7. Cont.

\begin{tabular}{|c|c|c|c|c|}
\hline Variable & $\begin{array}{c}\text { Innovation } \\
\text { Efficiency (Effc) }\end{array}$ & $\begin{array}{l}\text { Patent Output } \\
\text { (GPA) }\end{array}$ & $\begin{array}{l}\text { Innovation Efficiency }(\mathrm{Effc}) \\
\text { Introduction of Moderator }\end{array}$ & $\begin{array}{c}\text { Patent Output (GPA) } \\
\text { Introduction of Moderator }\end{array}$ \\
\hline CAS & $\begin{array}{c}1.04 \times 10^{-8} \\
-2.59 \times 10^{-8}\end{array}$ & $\begin{array}{l}-21.98^{* * *} \\
-2.611\end{array}$ & $\begin{array}{c}1.91 \times 10^{-8} \\
-2.65 \times 10^{-8}\end{array}$ & $\begin{array}{l}-21.63^{* * *} \\
-2.657\end{array}$ \\
\hline Property & $\begin{array}{c}3.93 \times 10^{-9} \\
-1.63 \times 10^{-8}\end{array}$ & $\begin{array}{l}-4.072 * \\
-2.306\end{array}$ & $\begin{array}{c}6.97 \times 10^{-9} \\
-1.62 \times 10^{-8}\end{array}$ & $\begin{array}{l}-3.890 * \\
-2.306\end{array}$ \\
\hline Age & $\begin{array}{l}-5.05 \times 10^{-9} * * \\
-2.26 \times 10^{-9}\end{array}$ & $\begin{array}{c}0.109 \\
-0.341\end{array}$ & $\begin{array}{c}-4.63 \times 10^{-9 * *} \\
-2.24 \times 10^{-9}\end{array}$ & $\begin{array}{c}0.147 \\
-0.342\end{array}$ \\
\hline Size & $\begin{array}{c}-4.04 \times 10^{-8 * * *} \\
-1.19 \times 10^{-8}\end{array}$ & $\begin{array}{l}22.79 * * * \\
-1.619\end{array}$ & $\begin{array}{c}-4.57 \times 10^{-8 * * *} \\
-1.16 \times 10^{-8}\end{array}$ & $\begin{array}{l}22.41^{* * *} \\
-1.641\end{array}$ \\
\hline Lev & $\begin{array}{l}-3.41 \times 10^{-7 * * *} \\
-1.20 \times 10^{-7}\end{array}$ & $\begin{array}{c}24.38 \\
-19.14 \\
\end{array}$ & $\begin{array}{c}-3.28 \times 10^{-7 * * *} \\
-1.17 \times 10^{-7}\end{array}$ & $\begin{array}{c}24.68 \\
-18.89\end{array}$ \\
\hline $\mathrm{Adv}$ & $\begin{array}{l}-7.67 \times 10^{-9} \\
-7.99 \times 10^{-8}\end{array}$ & $\begin{array}{l}-32.77^{* * *} \\
-9.457\end{array}$ & $\begin{array}{c}1.08 \times 10^{-8} \\
-8.08 \times 10^{-8}\end{array}$ & $\begin{array}{l}-32.05^{* * *} \\
-9.553\end{array}$ \\
\hline ROE & $\begin{array}{c}1.72 \times 10^{-7} \\
-2.30 \times 10^{-7}\end{array}$ & $\begin{array}{l}49.31 * * \\
-24.92\end{array}$ & $\begin{array}{c}2.03 \times 10^{-7} \\
-2.32 \times 10^{-7}\end{array}$ & $\begin{array}{l}54.16^{* *} \\
-25.43\end{array}$ \\
\hline RDs & $\begin{array}{c}-4.41 \times 10^{-6 * * *} \\
-5.90 \times 10^{-7}\end{array}$ & $\begin{array}{l}499.8^{* * *} \\
-65.77\end{array}$ & $\begin{array}{c}-4.69 \times 10^{-6 * * *} \\
-5.94 \times 10^{-7}\end{array}$ & $\begin{array}{c}485.4^{* * *} \\
-69.51\end{array}$ \\
\hline Constant & $\begin{array}{l}1.46 \times 10^{-6 * * *} \\
-2.60 \times 10^{-7}\end{array}$ & $\begin{array}{c}-493.5^{* * *} \\
-37.2\end{array}$ & $\begin{array}{c}1.50 \times 10^{-6 * * *} \\
-2.57 \times 10^{-7}\end{array}$ & $\begin{array}{c}-492.8^{* * *} \\
-37.56\end{array}$ \\
\hline Observations & 1242 & 1226 & 1242 & 1226 \\
\hline$R^{2}$ & 0.103 & 0.372 & 0.114 & 0.377 \\
\hline
\end{tabular}

Note: (1) The upper figure is the estimation coefficient and the lower figure is the cluster robustness standard error in the table; (2) ${ }^{* * *},{ }^{* *}$ and * indicate a significance level of $1 \%, 5 \%$ and $10 \%$, respectively. (3) The time period of this regression is 2012-2017.

It is obvious from analyzing Tables $5-7$ that all of our hypotheses are still fully supported. The correlation direction and significance level between the main variables have not substantially changed, which further validates the robustness of our research. Moreover, in Table 3, the chi-squared values of the four models are $0.078,0.087,0.35$, and 0.352 ; in Table 5, the chi-squared values of the four models are $0.125,0.14,0.357$, and 0.362 ; in Table 6 , the chi-squared values of the four models are $0.0923,0.101,0.357$, and 0.359; and in Table 7, the chi-squared values of the four models are 0.103, 0.114, 0.372 , and 0.377 . As a result, the regression results of the three robustness tests do not show significant differences with those in Table 3. The robustness of our results is thus assured.

\section{Conclusions}

\subsection{Discussion}

All four hypotheses were fully supported. With the sample of China's listed companies in the manufacturing sector, our empirical findings thus offer fresh insights into understanding the complex links between SCI and firm innovation performance considering the moderating role of the sustainable policy in affecting such relationships.

In terms of theoretical contributions, first and foremost, our results show that in Chinese manufacturing with intensifying environmental and social concerns, the degree of SCI negatively relates to firm innovation efficiency but positively relates to firm patent outcomes, which, to a certain extent, reflects the paradoxes between the pursuit of innovation quality and quantity and between CSR investment and innovation efficiency. To a certain extent, our findings, based on the theories of strategic management (i.e., RDT) and economics (i.e., TCT), are a response to the calls of operations management scholars for employing multiple domains to study SCI-related issues [12,23]. In light of the inconsistent results regarding the impact of SCI on firm innovation found in previous studies [1-3], we have therefore contributed to the supply chain literature by providing new, context-specific evidence and fruitful cross-disciplinary understanding. Additionally, our study implies that the rise of ecological 
concerns coupled with the popularity of digital technologies may result in the emergence of more dynamic mechanisms between the responsible management of SCI and organizational innovation among all stakeholders of the supply chain.

Second, according to Figures 1 and 2, our findings illustrate the positive and significant impact of the strategic emerging industry policy on SCI-innovation relationships. This sustainable policy weakens the negative association between $\mathrm{SCI}$ and innovation efficiency but strengthens the positive link between SCI and firm patent output. In line with the literature $[23,29,30]$; this study also highlights the predominate role the Chinese government plays in guiding firms' strategic direction and the importance of leveraging policy support to obtain more precious public resources over their rivals in a non-Western context. Despite Chinese firms being used to engaging in politically correct behaviors and complying with the national initiative, it is worth noting that the lack of effective policy implementation may still hamper the achievement of sustainable SCI [2].

As for the practical implications, our research offers novel insights for global managers and policy makers into understanding the complex interactions of firm sustainability and innovation in SCI. While for the past decades, numerous Chinese manufacturing firms had merely focused on increasing productivity and achieving economies of scale, our results shed some light on how these firms can capitalize on digital technology to more rapidly adapt to dynamic market changes and consumer demands, so as to cope with the new green challenges for sustainable innovation in the manufacturing sector. Viewed from this angle, we also provide practical implications about how manufacturing firms can adopt $\mathrm{SCI}$ as an effective means to deal with intensifying competition coupled with more serious CSR considerations in a new digitalized way. In addition, while green policy-induced innovation has gained much prominence in Europe, we expect that such sustainability-oriented innovation may also become a common practice in the Chinese context.

\subsection{Limitations of the Research and the Future Outlook}

This study is still subject to certain limitations and future research should take these into consideration. While the implementation of China's strategic emerging industry policy is a relatively recent phenomenon, we can only measure the short-term changes in innovation efficiency and patent output. Future research should consider a longitudinal research design, whereby the intricate relationships between SCI and innovation performance can be more clearly characterized.

We only used data from the manufacturing sector in mainland China as our sample, so future research should include a greater variety of industries and more regions because the characteristics of other industries are different and innovation cultures in different regions of China (e.g., Hong Kong, Taiwan, and Macao) may vary. Furthermore, while firm innovation should take into account the heterogeneities of SCI, it would be rather interesting to identify the multidimensional concept of SCI in the future.

Author Contributions: Conceptualization, Q.X. and T.C.; Data curation, Q.H., C.C. Y.S. and J.X.; Formal analysis, Q.H. and T.C.; Funding acquisition, Q.X.; Methodology, Q.H.; Resources, Q.X. and J.X.; Supervision, Q.X. and T.C.; Validation, C.C. and Y.S.; Writing—original draft, Q.H.; Writing—review \& editing, T.C., C.C. and Y.S.

Funding: This research was funded by the National Social Science Foundation of China (project No. 17BGL016).

Conflicts of Interest: The authors declare no conflict of interest.

\section{References}

1. Li, G.; Shao, S.; Zhang, L. Green supply chain behavior and business performance: Evidence from China. Technol. Forecast. Soc. Chang. 2017, 144, 445-455. [CrossRef]

2. Oelze, N.; Hoejmose, S.U.; Habisch, A.; Millington, A. Sustainable Development in Supply Chain Management: The Role of Organizational Learning for Policy Implementation. Bus. Strategy Environ. 2016, 25, 241-260. [CrossRef] 
3. Lii, P.; Kuo, F.I. Innovation-oriented supply chain integration for combined competitiveness and firm performance. Int. J. Prod. Econ. 2016, 174, 142-155. [CrossRef]

4. Brandenburg, M.; Govindan, K.; Sarkis, J.; Seuring, S. Quantitative models for sustainable supply chain management: Developments and directions. Eur. J. Oper. Res. 2014, 233, 299-312. [CrossRef]

5. Flynn, B.B.; Huo, B.; Zhao, X. The impact of supply chain integration on performance: A contingency and configuration approach. J. Oper. Manag. 2010, 28, 58-71. [CrossRef]

6. Wei, J.; Liu, Y. Government support and firm innovation performance. Chin. Manag. Stud. 2015, 9, 38-55. [CrossRef]

7. Chin, T.; Yang, Y.; Zhang, P.; Yu, X.; Cao, L. Co-creation of Social Innovation: Corporate Universities as Innovative Strategies for Chinese Firms to Engage with Society. Sustainability 2019, 11, 1438. [CrossRef]

8. Pero, M.; StößLein, M.; Cigolini, R. Linking product modularity to supply chain integration in the construction and shipbuilding industries. Int. J. Prod. Econ. 2015, 170, 602-615. [CrossRef]

9. Stock, J.R.; Boyer, S.L. Developing a consensus definition of supply chain management: A qualitative study. Int. J. Phys. Distrib. Logist. Manag. 2009, 39, 690-711. [CrossRef]

10. Oelze, N. Sustainable supply chain management implementation-enablers and barriers in the textile industry. Sustainability 2017, 9, 1435. [CrossRef]

11. Coase, R.H. The nature of the firm. Economica 1937, 4, 386-405. [CrossRef]

12. Mcivor, R. How the transaction cost and resource-based theories of the firm inform outsourcing evaluation. J. Oper. Manag. 2009, 27, 45-63. [CrossRef]

13. Mwai, N.W.; Kiplang'at, J.; Gichoya, D. Application of resource dependency theory and transaction cost theory in analysing outsourcing information communication services decisions. Electron. Libr. 2014, 32, 786-805. [CrossRef]

14. Bowden, B.; Insch, A. A study of resource dependency: The coal supply strategy of the Japanese steel mills-1960-2010. J. Manag. Hist. 2013, 19, 73-86. [CrossRef]

15. Czarnitzki, D.; Thorwarth, S. The Contribution of In-house and External Design Activities to Product Market Performance. J. Prod. Innov. Manag. 2012, 29, 878-895. [CrossRef]

16. Afuah, A. Dynamic Boundaries of the Firm: Are Firms Better Off Being Vertically Integrated in the Face of a Technological Change? Acad. Manag. J. 2001, 44, 1211-1228. [CrossRef]

17. Kapoor, R.; Adner, R. What Firms Make vs. What They Know: How Firms' Production and Knowledge Boundaries Affect Competitive Advantage in the Face of Technological Change. Organ. Sci. 2012, 23, 1227-1248. [CrossRef]

18. Lahiri, N.; Narayanan, S. Vertical integration, innovation, and alliance portfolio size: Implications for firm performance. Strateg. Manag. J. 2013, 34, 1042-1064. [CrossRef]

19. Li, H.L.; Tang, M.J. Vertical integration and innovative performance: The effects of external knowledge sourcing modes. Technovation 2010, 30, 401-410. [CrossRef]

20. Pfeffer, J.; Salancik, G.R. The External Control of Organizations: A Resource Dependence Perspective. Soc. Sci. Electron. Publ. 2003, 23, 123-133.

21. Koufteros, X.; Vonderembse, M.; Jayaram, J. Internal and External Integration for Product Development: The Contingency Effects of Uncertainty, Equivocality, and Platform Strategy. Decis. Sci. 2005, 36, 97-133. [CrossRef]

22. Kenderdine, T. China's Industrial Policy, Strategic Emerging Industries and Space Law. Asia Pac. Policy Stud. 2017, 4, 325-342. [CrossRef]

23. Chin, T.; Liu, R.-H.; Yang, X. Reverse internationalization in Chinese firms: A study of how global startup OEMs seek to compete domestically. Asia Pac. Bus. Rev. 2016, 22, 201-219. [CrossRef]

24. Chin, T.; Li, G.; Jiao, H.; Addo, F.; Jawahar, I.M. Career sustainability during maufacturing innovation: A review, a conceptual framework and future research agenda. Career Dev. Int. 2019. [CrossRef]

25. Lazzarini, S.G. Strategizing by the government: Can industrial policy create firm-level competitive advantage? Strateg. Manag. J. 2015, 36, 97-112. [CrossRef]

26. Du, J.; Lu, Y.; Tao, Z. Contracting institutions and vertical integration: Evidence from China's manufacturing firms. J. Comp. Econ. 2012, 40, 89-107. [CrossRef]

27. Kwon, T. Rent and rent-seeking in renewable energy support policies: Feed-in tariff vs. renewable portfolio standard. Renew. Sustain. Energy Rev. 2015, 44, 676-681. [CrossRef] 
28. Yang, Q.; Zhao, X. Are logistics outsourcing partners more integrated in a more volatile environment? Int. J. Prod. Econ. 2016, 171, 211-220. [CrossRef]

29. Chin, T.; Rowley, C.; Redding, G.; Wang, S. Chinese strategic thinking on competitive conflict: Insights from Yin-Yang harmony cognition. Int. J. Confl. Manag. 2018, 29, 683-704. [CrossRef]

30. Deng, G.; Zhao, S.; Zhu, N. Does refinancing incentive affect cash dividends policy? evidence from the semimandatory dividend policy in china. Emerg. Mark. Financ. Trade 2015, 51, 1099-1116. [CrossRef]

31. Tan, Y.; Tian, X.; Zhang, C. Privatization and Innovation: Evidence from a Quasi-Natural Experience in China. SSRN Electron. J. 2014. [CrossRef]

32. Charnes, A.; Cooper, W.W.; Rhodes, E. Measuring the efficiency of decision-making units. Eur. J. Oper. Res. 1978, 2, 429-444. [CrossRef]

33. Chen, K.; Guan, J. Measuring the Efficiency of China's Regional Innovation Systems: Application of Network Data Envelopment Analysis (DEA). Reg. Stud. 2012, 46, 355-377. [CrossRef]

34. Cruz-Cázares, C.; Bayona-Sáez, C.; García-Marco, T. You can't manage right what you can't measure well: Technological innovation efficiency. Res. Policy 2013, 42, 1239-1250. [CrossRef]

35. Carayannis, E.G.; Grigoroudis, E.; Goletsis, Y. A multilevel and multistage efficiency evaluation of innovation systems: A multiobjective DEA approach. Expert Syst. Appl. 2016, 62, 63-80. [CrossRef]

36. Bai, J.; Jiang, F. Research on regional innovation efficiency considering environmental factors-Based on three-stage DEA. Financ. Trade Econ. 2011, 10, 104-112.

37. Guo, D.; Guo, Y.; Jiang, K. Government-subsidized R\&D and firm innovation: Evidence from China. Res. Policy 2016, 45, 1129-1144.

38. Hughes, A.; Morton, M.S.S. The transforming power of complementary assets. MIT Sloan Manag. Rev. 2011, 47, 391-401.

39. Mardani, A.; Zavadskas, E.K.; Streimikiene, D.; Jusoh, A.; Khoshnoudi, M. A comprehensive review of data envelopment analysis (DEA) approach in energy efficiency. Renew. Sustain. Energy Rev. 2017, 70, 1298-1322. [CrossRef]

40. Lin, J.H.; Wang, M.Y. Complementary assets, appropriability, and patent commercialization: Market sensing capability as a moderator. Asia Pac. Manag. Rev. 2015, 20,1-7. [CrossRef]

41. Chan, H.W.; Faff, R.W. An investigation into the role of liquidity in asset pricing: Australian evidence. Pac.-Basin Financ. J. 2003, 11, 555-572. [CrossRef]

42. Stock, J.H.; Watson, M.W. Heteroskedasticity-robust standard errors for fixed effect panel data regression. Econometrica 2008, 76, 155-174. [CrossRef]

43. Cheng, H.; Qian, F. Research on the relationship between innovation performance and the power, stability and instruments of policy-Empirical analysis based on 2000-2009 industry panel data. Sci. Res. Manag. 2013, 34, 103-108.

44. Li, C.; Wang, D.; Zhang, H. First-order mixed integer-valued autoregressive processes with zero-inflated generalized power series innovations. J. Korean Stat. Soc. 2015, 44, 232-246. [CrossRef]

45. Afzal, M.N.I. An empirical investigation of the national innovation system (NIS) using data envelopment analysis (DEA) and the Tobit model. Int. Rev. Appl. Econ. 2014, 28, 507-523. [CrossRef]

46. Engler, P.; Tervala, J. Hysteresis and fiscal policy. J. Econ. Dyn. Control 2018, 93, 39-53. [CrossRef]

47. Li, W.; Zheng, M. Is it substantive innovation or strategic innovation?-Impact of macroeconomic policies on micro-enterprises' innovation. Econ. Res. J. 2016, 51, 60-73.

48. Wong, P.K.; Ho, Y.P.; Autio, E. Entrepreneurship, innovation and economic growth: Evidence from gem data. Small Bus. Econ. 2005, 24, 335-350. [CrossRef]

49. Chin, T.; Yang, Y.; Liu, R.; Li, Y.; Jiang, F. Innovation, commitment and turnover of front-line technical workers: A moderated mediation model. J. Manag. Sci. 2018, 31, $20-32$.

50. Chin, T.; Liu, R.; Yang, D.; Tsuei, D.; Hu, L.; Yang, Y. Effects of dynamic core competences on own brand strategy in reverse internationalization. J. Manag. Sci. 2017, 30, 27-38. 
51. Bosetti, V.; Cattaneo, C.; Verdolini, E. Migration of skilled workers and innovation: A european perspective. J. Int. Econ. 2015, 96, 311-322. [CrossRef]

52. Falk, M. Quantile estimates of the impact of R\&D intensity on firm performance. Small Bus. Econ. 2012, 39, $19-37$. article distributed under the terms and conditions of the Creative Commons Attribution (CC BY) license (http://creativecommons.org/licenses/by/4.0/). 